\title{
Landfill in a Sustainable Waste Disposal
}

\author{
Iyenoma ThankGod Osazee
}

\section{ABSTRACT}

Landfill is as old as mankind, and it is the most common and popular waste disposal globally; it is very likely to be the mostly used method for some time to come despite efforts to recycle and re-use waste materials. However, in many respects landfilling has been highly criticised by stakeholders and regarded as the opposite of sustainability because of the health hazard and environmental burden it constitutes. The efficiency of landfilling rests on technical, economic, and legal framework which seems to be inadequate in many countries. The essence of sustainable landfill is to ensure that the environmental parameters e.g., methane, leachate, etc. are reduced to acceptable risk level (inert waste) in order to prevent damage to humans and the environment. Many European countries in compliance with 2008/98/EC along with 94/62/EC Directive have been able to reduce heavy reliance on the landfill; however, this has raised the use of other waste management methods e.g., Sweden share of landfill disposal is $1 \%$ (Table I) this increases dependent on other methods of waste disposal e.g., incineration, $49 \%$, waste treated biologically, $14 \%$ in 2011 . Nevertheless, landfilling will still be required to dispose of waste which cannot be recycled or treated in other ways.

Keywords: acceptable risk, landfills, sustainability, waste disposal.
Published Online: August 20, 2021

ISSN: $2684-446 \mathrm{X}$

DOI : 10.24018/ejgeo.2021.2.4.165

\section{Iyenoma ThnakGod Osazee*}

Department of Health, Safety and Environment, Julius Berger Nigeria PLC, Abuja, FCT, Nigeria.

(e-mail: iyenomaosazee ${ }^{@}$ yahoo.com)

*Corresponding Author

\section{INTRODUCTION}

Landfill can be denoted as the physical facilities or places where (solid waste and waste residuals) are dumped, usually in controlled and studied way [1]. Landfill is as old as mankind and landfilling seems to be the most common and popular waste management choice. It is the conventional or traditional waste disposal which take the centre stage in waste management in many developed countries (Table I) and still popular in developing countries. This may be due to its relative ease of operation with less technicalities. In many respects, landfilling has been highly criticised and is being regarded as the opposite of sustainability apparently because of the health hazard and environmental burden it constitutes [2], [3]. Many researchers, stakeholders, regulators have advocated that landfill should be eliminated. There is waste biodegradation in landfills which create a greenhouse gas termed landfill gas [4]. This result to global warming and intensive climate change due to disturbance of the ozone atmosphere.

\section{A. Background Information to the Study}

It has been discussed severally that traditional or conventional landfills creates some severe environmental consequences in addition to occupation of large expanse of land. Solid waste management problems in every country cannot be overemphasised. The notion of entirely eradicating waste is unthinkable; rather, seeking the appropriate and scientific technique to handle wastes in a justifiable manner, which will ensure the protection of lives and properties, as well as conserve the environment. Conventional or traditional landfills fall short of three steps of the hierarchy of a new waste concept, which tends to drive sustainable landfills [5]; [6] sums it up thus: "The safe disposal of waste within a landfill, and its subsequent degradation to the inert state in the shortest possible time span, by the most financially efficient method available, and with minimal damage to the environment". The aim of the study was to look at the issues of landfilling as a viable waste management and that despite the perceived shortcoming, the approach may not easily be eased off in many countries. The focus of any sustainable landfill is to alleviate the environmental effects and consequences by reduction of toxic waste and contamination, prevention of leachate where practicable and closing inadequately managed landfill. The primary cause of the harmful nature of landfills is the accumulated quantity of waste which generate methane, high volume of leachate, indiscriminate dumping of waste among others. In the study conducted by [7] from 21 countries in 7 regions of the world, it showed varied regulatory limits of leachate contaminants composition in landfills. Depicted in Fig.1 are leachate volume in 6 countries (Table V) and carbon dioxide equivalent ranges that from 15.9 to $129.7 \mathrm{Mt}\left(\mathrm{CO}_{2}\right.$-eq [8]. These environmental parameters tend to determine the efficiency of the landfill and its ability to function without causing damage to humans and the environment.

The European Union (EU) have developed many directives aimed at reducing the number of landfills and quantity of waste generated. In 1999, EU Landfill Directive(1999/31/EC) was passed in order to encourage 
member countries to work towards a gradual reduction of Municipal Solid Wastes (MSW) to $75 \%$ of the 1995 disposal level by 2010 and $35 \%$ reduction by 2020 [9]. The outcome was the adoption of various methods for managing waste. This Legislative Act urges Member States to "take adequate measures to reduce the prevention and possible reduction of waste production with its attendant harmful effects". Feasibility study of 27 European countries was conducted in order to ascertain their share of landfill disposal in percentage. All countries surveyed make use of landfills at varying degree with the highest being Malta, 92\% and the least: Sweden, Netherlands, Germany; 1\%each (Table I).

TABLE I: MSW PRODUCED IN 1995 AND 2016(KG/CAPITA) ADOPTED FROM [10] AND SHARE OF LANDFILL DISPOSAL (\%) ADOPTED FROM [11]

\begin{tabular}{|c|c|c|c|c|}
\hline Country & 1995 & 2016 & 2017 & $\begin{array}{l}\text { Waste treatment - } \\
\text { landfill, } 2016 \text { (share } \\
\text { of landfill disposal) }\end{array}$ \\
\hline Austria & 480 & 552 & 570 & $3 \%$ \\
\hline Belgium & 446 & 414 & 409 & $1 \%$ \\
\hline Bulgaria & 831 & 404 & 416 & $64 \%$ \\
\hline Cyprus & 593 & $592 a$ & 637 & $81 \%$ \\
\hline $\begin{array}{c}\text { Czech } \\
\text { Republic }\end{array}$ & 312 & 339 & 344 & $50 \%$ \\
\hline Denmark & 521 & 777 & 781 & $1 \%$ \\
\hline Estonia & 370 & 327 & 390 & $12 \%$ \\
\hline Finland & 437 & 504 & 510 & $3 \%$ \\
\hline France & 476 & 510 & 513 & $22 \%$ \\
\hline Germany & 621 & 625 & 633 & $1 \%$ \\
\hline Greece & 331 & 498 & - & $52 \%$ \\
\hline Hungary & 377 & 380 & 385 & $51 \%$ \\
\hline Ireland* & 430 & 615 & - & $22 \%$ \\
\hline Italy & 468 & 436 & 489 & $28 \%$ \\
\hline Latvia & 184 & 367 & 438 & $72 \%$ \\
\hline Lithuania & 542 & 422 & 455 & $31 \%$ \\
\hline Luxemburg & 587 & 614 & 607 & $17 \%$ \\
\hline Malta & 387 & 584 & 604 & $92 \%$ \\
\hline Netherland & 509 & 518 & 513 & $1 \%$ \\
\hline Poland & 284 & 307 & 315 & $37 \%$ \\
\hline Portugal* & 351 & 483 & 487 & $49 \%$ \\
\hline Romania & 254 & 228 & 272 & $80 \%$ \\
\hline Slovakia & 294 & 344 & 378 & $66 \%$ \\
\hline Slovenia** & 469 & 434 & 471 & $24 \%$ \\
\hline Spain & 365 & 443 & 462 & $57 \%$ \\
\hline Sweden & 386 & 442 & 452 & $1 \%$ \\
\hline $\begin{array}{c}\text { United } \\
\text { Kingdom* }\end{array}$ & 501 & 476 & - & $28 \%$ \\
\hline
\end{tabular}

*Data from 2014; **Data from 2015.

\section{The LANDFILl SitE}

Landfill sites are major habitation of methane, " $45 \%$ of UK methane emanate are from landfill sites" [12]. Fig. 1 conveys information of 2010 records of ten top countries in the world that emits methane with USA topping the list with $129.7 \mathrm{mmtCO}_{2}$-eq [8].

The water that flows into the landfill creates leachate which has the possibility of polluting the surroundings and the environment. Other problems related to leachate include groundwater pollution and oxygen reduction and ecotoxicity (potential adverse effects of biological, chemical, or physical agent on the ecosystems) in surface waters [13], [14]. These issues from the landfilling have raised a red flag among stakeholders and regulators as to whether this method of waste disposal should continue to be entertained. The fact is that every country practice landfilling at different levels as discussed in Table I. Some countries have put regulations in place to contain the menace from the landfills. Sweden have even taken the initiative of converting the landfill gas mainly carbon dioxide and methane to source of energy. The world population is currently about 8 billion people [15] and this has tremendous impacts on the volume of waste generated. The big picture of waste generated globally is depicted in Fig. 2 projected to 854 million by 2050 .

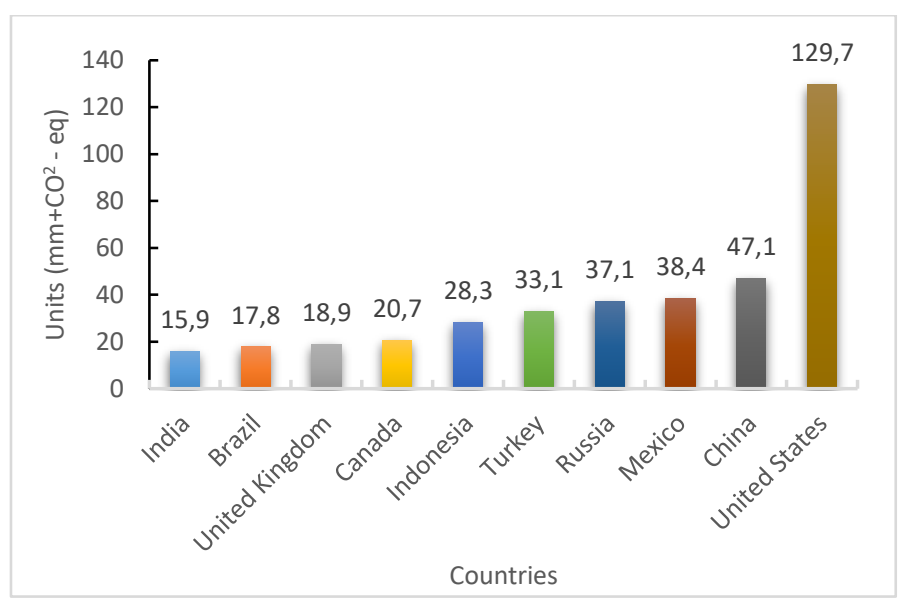

Fig. 1. Methane Emissions from Landfills in ten countries [8].

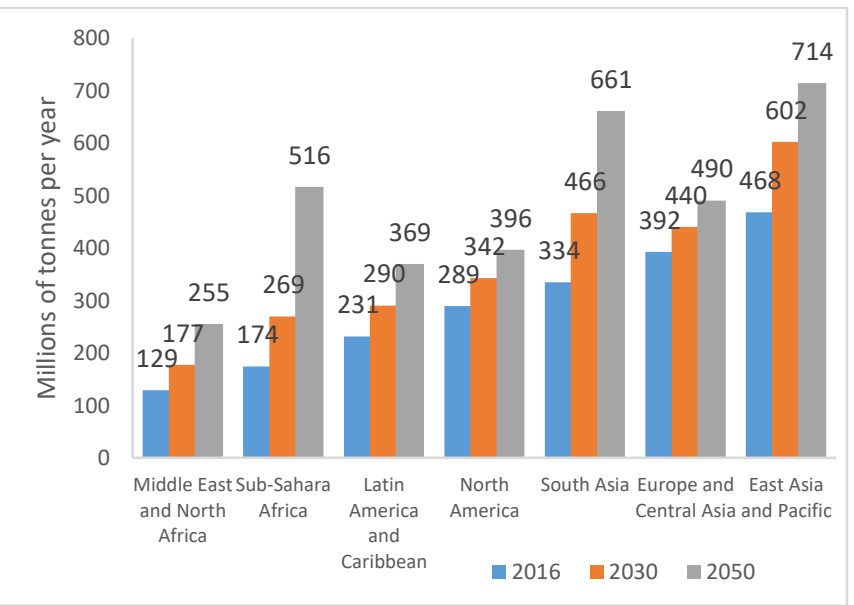

Fig. 2. Waste generated by various regions of the world [15].

\section{A. Laws, Regulations and Policies}

The term Environment Impact Assessment (EIA) as well as referred to as Impact Statement (European Council Directive $85 / 337 /$ EEC of June 27, 1985) defined it as a "process of description and assessment of the direct and indirect effects of a project on humans, fauna and flora, soil, water, air, climate and the landscape, the interaction of these factors on material assets and the cultural heritage" [16].The focus on EIA report is to help policy and decision makers consider the environmental impacts of any (landfill) project concluding on whether to continue with the new developments or not. This gave birth to concerted effort to strengthen the procedure so that it could respond to new challenges posed by escalating global environmental problems and degradation. These comprise global warming from greenhouse gases (GHGs) and climate change, ozone layer depletion, biodiversity loss, marine water degradation, pollution, and poverty, all of which are reflections of unsustainable practices in resource management and development.

In order to assess the adverse possible effects of any landfill on the environment and surrounding, including the communities where the proposed project will be cited, a 
detailed analysis of geotechnical, environmental and geophysical examinations, etc. are required. The EIA report attempts to determine the effects and hazards of the proposed landfill on the existing relationship between the surroundings and its inhabitants will help determine its appraisal and feasibility. "Council Directive 85/33/EC" discussed the need to conduct an Environmental Impact Assessment in respect of finding the undesirable impacts for some types of projects in the public and the private sectors within the environment".

\section{B. European Union Directive (1999/13/EC) on Waste Disposal Landfill}

This Directive centred on waste disposal in landfill and is popularly referred to as "Council Directive" of April 26, 1999. It was transmitted by the EU to Member States for adoption and domesticated locally on July 1, 2001. The Directive has its main objective, thus: "Prevent or reduce to the barest minimum adverse effects or consequences being faced by the physical environment, with due attention to pollutions for the source of water, underground aquifers, soil structures, air quality, the effect of greenhouse gases (GHGs) and any other dangers that have affected the wellbeing of persons as a result of disposal of waste on landfills, within the lifespan of any landfills."

EU Commission raised a legislative idea directed at meeting targets within the landfill operation. These targets, which includes recycling and other related aspects, were clearly spelt out in 2008/98/EC Directive alongside 94/62/EC Directive which centres on packaging wastes. The main contents of the proposal are aimed at the gradual phasing out landfilling of waste and due to be completed by the year 2025 for waste that can be recycled. These consists of all forms of plastic, metal, paper, bio-wastes, and glass. While nonhazardous waste landfilling sites, this is expected to tally with $25 \%$ maximum limit of landfilling sites. Proposals and actions are aimed at making the landfills more efficient and environmentally friendly.

In order to enforce the Legislative Directive (1999/13/EC), the EU spelt out the approach in which permit shall be granted to operate the landfill site to include: full details of the applicant(s), description of the types, forms and total quantity of the wastes to be dumped, total design capacity of proposed site(s), details of the location of the proposed site for ease of access, planned method of preventing and reduction of pollution and proposal put in place to enhance monitoring and reduction of pollution.

\section{The CONCEPT OF SUSTAINABLE DEVELOPMENT}

The term sustainable development can actually mean different thing to so many people; as a result, it is difficult to pin down. Conceptually, it is centred on meeting the needs of the present generation without precluding subsequent generations (Brundtland's Commission) [17]. This means everyone understands or appreciate the need for growth and to grow the economy. However, it is not everyone that seems to look at the negative influences on development and wellbeing. The 17 Millennium Development Goals (MDGs) drive the scheme termed sustainable development. It is about the big picture as the goals helps to create innovative technologies without causing damage to the surrounding. At the core of its procedure is the technique that takes earth's resources into due consideration.

Brundtland's Commission Concepts and WCED's opinion [17] tried to demonstrate the challenges and the need for policy guidelines to reduce harm and negative influence on the environment and surrounding. The process of acquiring site for landfill to actual construction has brought a lot of issues to the environment e.g., clearing the place of trees and other natural habitats in the land; the ecosystem is altered. The physical existence of landfill sites tantamount to emission of offensive odours and leachate gases. This has made arguments by environmental analysts strong, as they contend that landfills are not sustainable. However, control of the gases emitted may have long effect of reducing any possible outbreak of diseases in the area. Nevertheless, protection and preservation of the environment from wastes indiscriminately disposed of did not become a major issue of great concern until the 1970s. It was after then that the technical standards improved, laying emphasis mainly on the control of gases and leachates from landfills. This was what led U.S Environmental Protection Agency to establish the Resource Conservation and Recovery Act, which reinforced the procedures on landfills and better environmental protection [18].

The development of high quality and viable waste management practices are significant in the protection and promotion of the health of future generations. The stand point of sustainable development is that, it is practically possible to have development that attain the demands of the present world population for food, water, energy and shelter without causing harms on health and on the environment, and, not damaging or depleting the global resource base, and not precluding the capability of subsequent generations to meet their own needs [19]. Bad or poor solid waste management could have high level underground water contamination, which may cause infectious diseases and eventual deaths. EIA report can be used to assess the net contribution of a project or programme to sustainable development [20]. This was done by reiterating that the limitation of project-level impact restricts its scope to the project's capability to promote or impair sustainable development. This notwithstanding, also observed that some projects clearly promote sustainability through, for example, restoring the soil or reducing damage to the natural resource base arising from economic activity. What needed to be explored at this point, was finding a means of applying sustainability criteria in a project-level EIA. Such method faces two major problems. The first has to do with the nature of sustainable development, which is a "process encompassing the entire economy (or the global economy) in its relationship to the natural order". This suggests, by implication, that sustainable development cannot be realised by project valuation and selection. The second is that since conventional project-level EIA is limited to the treatment of the potential environmental damage of a project, a full assessment of the entire process will be required. According to [21]: one way of achieving full environmental and resource accounting (that is, the sustainability criterion) is:

- to appraise the impact of the project on the natural resource base and to take account of the adverse effects in the social costs and the positive effect in the societal benefits. All 
unabated environmental effects, such as pollution of the atmosphere, the oceans, the waterways, and the land would be internalised so that they become part of the social costs of the project. All natural resource depletion, such as the extraction of minerals, deforestation and ocean fishing, would be indicated as social costs, while any rise in renewable natural resources would be added up to the societal benefits.

\section{A. Landfill Lifespan}

Leachates from both industrial and non-hazardous wastes are toxic in contents; however, the waste from industrial sources are more toxic and the quantity of leachate produced hinges on the size of the landfills, the weather, that is, meteorological and hydrological parameters and efficiency of the capping. This explains why the quantity of leachate produced may be high in humid regions or high runoff and shallow water table [22], [23]. The geology and hydrogeology of any prospective landfill site has a lot to do with the level of natural protection of groundwater from pollution by landfill as this will have a healthy influence on the effectiveness and operation of the landfill. Available literature reveals that landfill leachate has high level of Biochemical oxygen demand, Chemical oxygen demand, Ammonia, Chloride, Sodium, Potassium and Boron. According to [24] the condition within a landfill can vary with respect to time and age; hence, there is likelihood of aerobic to anaerobic, which creates room for different chemical reactions to occur.

\section{B. Indicators of Sustainable Development in a Country}

Sustaining the environment and surrounding means respect for ecology reliability, carrying capability and preservation of natural resources, including plants and animals' habitats (biodiversity) [25]. Sustainability is a character or element of organisations that sustain themselves over a period; it is not static or an immovable endpoint that can be distinct. According to [26], it is much a broader occurrence than sustainable development, accepting ethical standards relating to the existence of living matter, to the rights of future and subsequent generations and to organisations accountable for ensuring that such rights are entrenched in policies and actions. The appropriate manner to discuss and assess sustainability from environmental perspective is to lay emphasis on natural resource reduction and to know whether the present rates of resource use can be continued in the near future [27].

Some indicators that can be used to evaluate the environmental sustainability of a country [28] are:

- a country whose environmental systems are preserved at healthy levels, and it is seen as improving rather than declining;

- $\quad$ if the levels of anthropogenic (majorly environmental pollution and pollutants emanating in human activity (e.g., emissions of sulphur dioxide) stress are low or adequate to stimulate no noticeable damage to its environmental systems;

- $\quad$ to the magnitude that people and social systems are not prone to environmental disturbance that affect human wellbeing; becoming less susceptible is a sign that a society is on track to more sustainability;

- $\quad$ to the level that institutions are in place that will help to monitor social dimensions of skills, attitudes and networks that encourage efficient reactions to environmental issues and problems;

- if it works cooperatively with other countries in the management of identified environmental problems and help in reducing adverse transboundary, environmental effects on other countries to the degree that cause no appreciable harm.

TABLE II: TECHNICAL REQUIREMENTS RELATING TO FORMATION AND MANAGEMENT OF LANDFILL LEACHATE ACCORDING TO ANNEX 1 OF THE EU LANDFILL DIRECTIVE (1999/31/EC). $\mathrm{K}=$ PERMEABILITY ADAPTED FROM [4] Landfill for inert Landfill for non- Landfill for waste hazardous waste hazardous waste

\begin{tabular}{|c|c|c|c|}
\hline & waste & nazardous waste & nazardous waste \\
\hline $\begin{array}{c}\text { Measures to } \\
\text { prevent } \\
\text { infiltration }\end{array}$ & Not required & Required & Required \\
\hline $\begin{array}{l}\text { Leachate } \\
\text { collection and } \\
\text { treatment }\end{array}$ & Not required & Required & Required \\
\hline $\begin{array}{l}\text { Geological } \\
\text { barrier }\end{array}$ & $\begin{array}{l}\mathrm{K} \leq 1.0 \times 10^{-7} \mathrm{~m} \cdot \mathrm{s}^{-1} \\
\text { Thickness } \geq 1 \mathrm{~m}\end{array}$ & $\begin{array}{c}\mathrm{K} \leq 1.0 \times 10^{-9} \mathrm{~m} \cdot \mathrm{s}^{-1} \\
\text { Thickness } \geq 1 \mathrm{~m}\end{array}$ & $\begin{array}{c}\mathrm{K} \leq 1.0 \times 10^{-9} \mathrm{~m} \cdot \mathrm{s}^{-1} \\
\text { Thickness } \geq 5 \mathrm{~m}\end{array}$ \\
\hline $\begin{array}{c}\text { Artificial } \\
\text { sealing layer }\end{array}$ & Not required & Required & Required \\
\hline $\begin{array}{c}\text { Drainage } \\
\text { Layer }\end{array}$ & Not required & Required & Required \\
\hline
\end{tabular}

\section{LANDFILLS LEACHATES}

According to EU Directive, landfill has three categories: landfill for inert waste, for non-hazardous waste and for hazardous waste. This classification also depicts (The Council Decision (2003/33/EC)) the type of waste they accept. The technical requirements relating to leachate formation and management are tabulated in Table II. The practice in Sweden is that landfills for non-hazardous and hazardous waste must be supplied with top cover as soon as possible after the completion of landfilling. This has helped to reduce the overdependence on landfill tremendously: [29] posited that $1 \%$ of MSW was landfilled in 2010, while $49 \%$ was incinerated, $36 \%$ recycled, $14 \%$ treated biologically and $1 \%$ was hazardous waste in Sweden. This was done in order to reduce the amount of leachate formed and contaminant mobilised [30] and reduce over dependent on landfills. This is in line with international and national determination towards enhancing a climate-friendly waste management which should comply with the waste management hierarchy; it gives priorities to waste prevention, reuse, recycling (including composting) and energy recovery from waste before landfilling.

All domestic waste and to a large extent waste raised from the industry will generate leachate. However, domestic waste regular composition usually produce leachate; while in the case of industrial setting, it is highly variable. Table III depicts the composition of leachate and their classification according to age. $\mathrm{pH}$ of leachate tends to increase with age; whereas reverse is the case for COD as it correspondingly decreases with age while the concentration of $\mathrm{NH}_{3}$ increases [31]. However, the chemical composition is highly dependent on the phase of the sample collection. If sample was collected during the acid phase of decomposition, the $\mathrm{pH}$ value will be low and concentration of the BOD, COD, nutrients and heavy metals will be high; whereas the $\mathrm{pH}$ will be high and BOD, $\mathrm{COD}$ and nutrients value lower in the fermentation phase[12]. The primary GHGs such as $\mathrm{CO}_{2}, \mathrm{CH}_{4}$ and $\mathrm{N}_{2} \mathrm{O}$ occurs 
naturally, however, [32] indicated in their work that their concentrations are highly influenced and dictated by human activities such as dumping of waste in the landfill. In the past two centuries, human activities, remarkably the combustion of fossil fuels and changes in land use, have brought about more concentrations of GHGs in the atmosphere, causing a measurable warming of the atmosphere.

TABLE III: TYPICAL COMPOSITION OF LEACHATE IN RECENT, INTERMEDIATE AND OLD LANDFILLS [33]

\begin{tabular}{|c|c|c|c|}
\hline Parameter & $\begin{array}{l}\text { Recent } \\
\text { landfill }\end{array}$ & $\begin{array}{c}\text { Intermediate } \\
\text { landfill }\end{array}$ & Old landfill \\
\hline Age (years) & $<5$ & $5-10$ & $>10$ \\
\hline $\mathrm{pH}$ & 6.5 & $6.5-7.5$ & $>7.5$ \\
\hline $\mathrm{COD}(\mathrm{mg} / \mathrm{l})$ & $>10000$ & $4000-10000$ & $<4000$ \\
\hline $\mathrm{BOD} / \mathrm{COD}$ & $>0.3$ & $0.1-0.3$ & $<0.1$ \\
\hline $\begin{array}{l}\text { Organic } \\
\text { compounds }\end{array}$ & $\begin{array}{c}80 \% \\
\text { volatile } \\
\text { fatty acids } \\
\text { (VFA) }\end{array}$ & $\begin{array}{c}5-30 \% \text { of VFA+ } \\
\text { humic and fulvic } \\
\text { acids }\end{array}$ & $\begin{array}{l}\text { Humic and } \\
\text { fulvic acids }\end{array}$ \\
\hline Heavy metals & $\begin{array}{l}\text { Low- } \\
\text { medium }\end{array}$ & Low-medium & Low \\
\hline Biodegradability & High & Medium & Low \\
\hline
\end{tabular}

Method of gas collection in landfill has short term effect with a potential long-term effect depending on the leachate parameters e.g. in dissolved toxic compounds: short-effect are high concentration of direct toxic to humans and aquatic life; while potential long-term effect exhibit high bioaccumulation or bio-magnification leading to toxic effect (Table IV). However, the volume of leachate varies from country to country. For instance, Sweden generates an average of 250-300 mm of leachate annually which reduces to $10-40 \mathrm{~mm}$ annually on clay-capped layer wastes below field capacity; whereas Denmark generates $350 \mathrm{~mm}$ leachates annually during operation but reduces to $75 \mathrm{~mm}$ annually after capping [37]-[39].

In landfill emissions, the Intergovernmental Panel on Climate Change (IPCC) has set an international convention to not report $\mathrm{CO}_{2}$ discharged as a result of landfill decomposition. This is because biogenic carbon is considered and discussed under the 'land use/land use change and forestry'. This clearly explains while methane emissions are reported in landfills; it is usually denoted as tonnes of $\mathrm{CO}_{2}$ corresponding (that is 1 tonne of methane is denoted as 25 tonnes of $\mathrm{CO}_{2}$-eq) [35]. However, in practice, methane emissions from landfills are seldom determined or measured, instead estimated for reporting.

TABLE IV: POTENTIAL EFFECTS OF LEACHATE ON WATER RECEPTOR (MiNisTRY OF ENVIRONMENT: A GUIDE FOR THE MANAGEMENT OF ClOSING AND Closed LANDFILls IN NEW ZEALAND AT [34]

\begin{tabular}{|c|c|c|}
\hline Leachate parameter & Short-term effect & Potential long-term effect \\
\hline $\begin{array}{l}\text { Dissolved toxic } \\
\text { compounds }\end{array}$ & High concentration directly toxic to human, stock or aquatic life & $\begin{array}{c}\text { Bioaccumulation or biomagnification leading } \\
\text { to toxic effect }\end{array}$ \\
\hline High dissolve solids & $\begin{array}{c}\text { Increased salinity altering ecology and reducing value of } \\
\text { surface water for abstraction }\end{array}$ & Groundwater contamination \\
\hline High suspended solids & $\begin{array}{c}\text { Reduction of light inhibiting macrophyte growth; sedimentation } \\
\text { causing smothering of aquatic life; organic particles increasing } \\
\text { deoxygenation through microbial breakdown }\end{array}$ & $\begin{array}{l}\text { Habitat alteration: absorbed contaminants } \\
\text { increase toxicity }\end{array}$ \\
\hline $\begin{array}{l}\text { Immiscible organic } \\
\text { chemicals (e.g. oils and } \\
\text { solvents) }\end{array}$ & $\begin{array}{l}\text { Direct toxicity to humans, stock, and aquatic life; reduction in } \\
\text { reoxygenation rates through water surface; visible surface films }\end{array}$ & $\begin{array}{l}\text { Possible carcinogenic and mutagenic effects } \\
\text { on aquatic life; deoxygenation }\end{array}$ \\
\hline High oxygen demand & Deoxygenation of surface water & Deoxygenation; ecosystem changes \\
\hline Organic matter & Reduced oxygen levels & Deoxygenation; ecosystem changes \\
\hline Nutrients (e.g. nitrate) & Plant/algal blooms & Eutrophication \\
\hline
\end{tabular}

TABLE V: LEACHATE VOLUMES IN SOME EUROPE COUNTRIES [36]

\begin{tabular}{|c|c|c|}
\hline Country & Leachate volumes & Reference \\
\hline Sweden & $\begin{array}{l}\text { Average for Sweden } 250-300 \mathrm{~mm} / \mathrm{a} \text {. } \\
\text { 10-40mm/a from a clay-capped test cell } \\
\text { containing wastes below field capacity. }\end{array}$ & [37] \\
\hline Denmark & $\begin{array}{l}\text { 1. } 350 \mathrm{~mm} / \mathrm{a} \text { during operation } \\
2 . \quad(\mathrm{cf} . \mathrm{R} \sim 714 \mathrm{~mm} / \mathrm{a}) \\
75 \mathrm{~mm} / \mathrm{a} \text { after capping. }\end{array}$ & [38] \\
\hline & $\begin{array}{c}\text { 3. 320-400mm/a during operation } \\
\text { 4. }(\mathrm{R} \sim 633 \mathrm{~mm} / \mathrm{a}) \text {. } \\
56-89 \mathrm{~mm} / \mathrm{a} \text { after capping }\end{array}$ & [39] \\
\hline Germany & $\begin{array}{c}\text { Data } 21 \text { operational sites: R 510-1160 mm/a). } \\
\text { Leachate } \sim 25-340 \mathrm{~mm} / \mathrm{a}(4-35 \% \mathrm{R}) \text {. } \\
\text { Low values were from young landfills } \\
\text { High values were from older landfills where } \\
\text { absorptive capacity was used up. }\end{array}$ & [40] \\
\hline Spain & $\begin{array}{c}7 \mathrm{~mm} / \mathrm{a} \text { during 2-year period (R 400mm/a). } \\
\text { Site near Madrid }\end{array}$ & [41] \\
\hline Italy & $82 \mathrm{~mm} / \mathrm{a}$. Site near Pavia. & [42] \\
\hline Greece & $\begin{array}{l}11-15 \mathrm{~mm} / \mathrm{a} \text { collected but some also lost to } \\
\text { groundwater. Total estimated at } 40-60 \mathrm{~mm} / \mathrm{a}(\mathrm{R} \\
387 \mathrm{~mm} / \mathrm{a} \text {, ER } 60-100 \mathrm{~mm} / \mathrm{a}) \text {. Site near Athens. }\end{array}$ & [43] \\
\hline
\end{tabular}

\section{IMPACTS OF ClIMATE CHANGE ON WASTE MANAGEMENT}

Climate change is the direct or indirect contribution of human activities e.g. dumping of waste in landfill, bush burning, etc. which alters the global atmospheric composition and this tend to align with the natural climatic variability measured over a comparable period of time [44]. The climate change is considered by friends of the environment as one of the mostly deadly environmental challenges mankind are being exposed to. The climate change causes the sea level to rise, increased occurrence of cyclones plus irregular circulation of rainfall, whose consequences are negative impacts on agriculture production (low yields), plants and animals' habitats (biodiversity) and natural cycles. These natural instabilities are ascribed to the global warming sensation due to global emission of GHGs such as carbon dioxide $\left(\mathrm{CO}_{2}\right)$, methane $\left(\mathrm{CH}_{4}\right)$ and nitrogen $\left(\mathrm{N}_{2} \mathrm{O}\right)$ from anthropogenic activities [45]. According to [46], they attributed the Global Warming Potential of $\mathrm{CH}_{4}$ as 21 times, $\mathrm{N}_{2} \mathrm{O}$ as 310 times more than $\mathrm{CO}_{2}$ over a period of 100 years.

Waste production and composition differs between countries and within countries. The reasons for this, though not exhaustive, includes differences in population, urbanisation, and lifestyle. A typical controlled landfill involves the process of waste burial and coverage of deposits with, usually a low permeability material which help generates an interior environment that aids methane producing bacteria. The conditions, which help to create greater production of landfill gases due to improved 
biochemical activity that is similar to any ecological system are optimal conditions of temperature, moisture and nutrient source. The impacts of the variables, viz: temperature, humidity, precipitation etc. and their possible impacts on waste management have been analysed in Table VI e.g., temperature can cause a decline in air quality which could be detrimental to people having prevailing disease conditions. There are concerns among interests' groups of the build-up of
Carbon 11 oxides as well as some of the GHGs within the atmosphere. The indices of environmental warming are rise in sea level which result in severe flooding of the coastal communities, sporadic outbreak of diseases and increase in death rate, low yield from agricultural activities, negative effects on the ecosystems and possibility of losing the biodiversity [47].

\begin{tabular}{|c|c|c|}
\hline $\begin{array}{l}\text { Climate } \\
\text { Variable }\end{array}$ & Possible Climate Change & Possible Impacts on Waste Management Process \\
\hline Temperature $\left({ }^{\circ} \mathrm{C}\right)$ & $\begin{array}{l}\text { - Annual warmness between } 1{ }^{\circ} \mathrm{C} \text { to } 5^{\circ} \mathrm{C} \text { in the } \\
\text { year } 2080 \mathrm{~s} \\
\text { - More hotter days prevail usually during dry } \\
\text { season } \\
\text { - Eventually cold weather days reduce usually } \\
\text { in wet season } \\
\text { - Persistent anticyclone static summer days }\end{array}$ & $\begin{array}{l}\text { - More water requirement on site processes and workers } \\
\text { alike } \\
\text { - Declined air quality \& detrimental heat impact on } \\
\text { vulnerable people } \\
\text { - Affects biological systems like composting } \\
\text { anaerobically digestions } \\
\text { - More risk increase with varying distributions of pets } \\
\text { and insects }\end{array}$ \\
\hline Precipitation & $\begin{array}{l}\text { - Southern zone of Nigeria experiences more } \\
\text { wet days } \\
\text { - Increasingly on precipitation intensities in wet } \\
\text { season }\end{array}$ & $\begin{array}{l}\text { - Higher changes of flooding's from tidal, sea surface, } \\
\text { ground, and surface water bodies } \\
\text { - Stability of slopes on waste could be affected due to } \\
\text { increasing intensity of precipitations } \\
\text { - Affects biological systems like composting } \\
\text { anaerobically digestions }\end{array}$ \\
\hline Cloud covers & Level of cloud covers reduces & $\begin{array}{l}\text { - Exposure to sunlight intensity affect workers skins in } \\
\text { the event of outdoor working process }\end{array}$ \\
\hline Humidity & $\begin{array}{l}\text { Certain humidity will increase usually during wet } \\
\text { weather }\end{array}$ & $\begin{array}{l}\text { Has implication on outdoors biological activities within } \\
\text { the environment }\end{array}$ \\
\hline Sea Levels & $\begin{array}{l}\text { Average sea levels can increase its volume to } \\
\text { about } 86 \mathrm{~cm} \text { beyond its present levels as a result } \\
\text { of thermal increase as well as land movement by } \\
\text { the year } 2080 \text { s }\end{array}$ & $\begin{array}{l}\text { Inundations to waste management facility and with } \\
\text { increase to erosions within the coastal environment }\end{array}$ \\
\hline
\end{tabular}

\section{LANDFILl MANAGEMENT STRATEGIES}

The overall target of landfill strategies and application of regulations is sustainability. Landfill sustainability can be discussed under the concept of acceptable risk. This connote a proper way of achieving final storage quality of final stability: “(...) when the waste mass, post-closure, does not pose a threat to human and the environment (..)" and the landfill no longer require elaborate management or monitoring [49], [50]. However, in many countries, the actual final storage quality has not been clearly defined [51]; instead, the acceptance criteria for inert waste could be used as the leaching limit. The acceptance criteria for inert waste on leaching limit values [52] are typically based on compliance with drinking water standards in the groundwater [36]. This seems to agree with the European Commission that has indirectly defined emissions as a landfill that meets the acceptance criteria for inert waste [53]. Effective landfilling has at its root in planning at the design stage. Aside from the many geotechnical aspects in landfill designs; the selection of optimal location; consideration should be given to environmental, geotechnical, and physical appraisals [54]. At the forefront of landfill designs are effective monitoring system, good leachate management and waste settlement investigation [55]. Landfill should only be constructed where there are buffer zones between the site and the population with acceptable distance as may be dictated by relevant regulations, between a landfill site and where people reside [56]. The efficiency of the landfill operations rest on technical, economic, and legal framework which seems inadequate in many countries. Commitment and resilience on the part of stakeholders will improve the present situation. In addition, public and private institutions should be encouraged to undertake research in the field of environmental protection and management.

The advantages of bioreactor landfills have generated a shift from the conventional approach to utilisation of landfill gas generation and deployment of bioreactors [57]. One technique employed in many countries for the pre-treatment of MSW is mechanical and biological treatment (MBT). MBT has many aims, viz: to reduce landfill space, recover useful materials and stabilise biodegradable waste before landfilling. This helps to improve quality and lessen the possible risk of settlement, landfill gas production and the need for aftercare [58]-[60]. Monitoring of any landfill site should be taken as a priority. The period for commencement of monitoring of landfill and the duration after the closure of landfill was extensively reported in the work of [7] including the fact that landfill sites after closure consist of inert waste that may generate landfill gas. This account for why all landfill sites should be monitored irrespective of the types of waste for gas formation and migration. The records and findings and measurements taken will help in ascertaining the depth of possible changes that may have taken place over the period as this will provide the basis for detail information of greenhouse gases emission. This is due to increasing concern about climate change and the effects of global warming. GHG emissions have also emerged as hot topic in research on source identification and management [61], [62]. 


\section{CONCLUSION}

The population of the world in on the increase and this tend to pose more challenges for the various stakeholders in the field of waste management. Sustainable landfilling requires the combination of legal, economic, and technical framework in order to meet the challenging volume of waste generated due to population increase. Application of Bioreactor technique for biodegradable wastes should be implemented in the landfill as it aims at accelerating the biodegradation processes. This helps to curtail contamination from the landfill which can be a major source of the spread of sicknesses and diseases to the population. This has brought about increased concern for information of climate change and the effects of global warming.

The development of high quality and viable waste management practices are significant in the protection and promotion of the health of future generations. A healthy environment is imperative to the effective execution of environmental strategies. This is paramount for the countries to attain the goals of global initiatives, especially the Millennium Development Goals. A clean and environmentally friendly habitat should be the desire of every country. It beholds on everybody to work assiduously to reduce environment degradation and its impacts. The legal and technical principles of many countries in respect of waste management should be strengthened as this will help raise the economic venture of the project e.g., by practicing waste to energy programmes.

It is obvious that many countries are making frantic efforts in increasing recycle and re-use of materials, landfilling will still be required to dispose of waste which cannot be recycled or treated in other ways. It is imperative that efforts should be made towards enhancing a climate-friendly waste management in compliance with the waste management hierarchy of waste prevention, reuse, recycling (including composting) and energy recovery from waste before landfilling. Nevertheless, many developing countries who are still lacking in developing other efficient methods of waste disposal will definitely consider landfilling due to its ease of operation.

\section{REFERENCES}

[1] Zabaleta, A. (2008): Sustainability Indicators for Municipal Solid Waste Treatment - Case study - The City of Stockholm: landfill vs incineration. Master of Science Thesis presented to Industrial Ecology Royal Institute of Technology, Stockholm.

[2] Ettler, V., Mihaljevic, M., Matura, M., Skalova, M., Sebek, O., and Bezdicka, P. (2008): Temporal variation of trace elements in waters polluted by municipal solid waste landfill leachate. Bulletin of Environmental Contamination and Toxicology 80(3), 274-2095. Oman and Junestedt, 2008.

[3] Kalcikova, G., Vavrova, M., Zagorc-Koncan, J., and Zgajnar Gotvajn, A. (20110: Seasonal variations in municipal landfill leachate quality. Management of Environmental Quality 22(5), 612-619.

[4] Modin, H. (2012): Modern landfill leachate - quality and treatment Water Resources Engineering, Lund University, Sweden.

[5] Wagner, J. (2011): Incentivizing sustainable waste management. Ecological Economics 70:585-594.

[6] Allen, A. (2001): Containment landfills: the myth of sustainability. Engineering Geology. Volume 60, 3-19.

[7] Osazee, I.T., SenGupta, B. (2021): Environmental Consequences of Poor Landfill Management. European Journal of Environment and Earth Sciences. DOI: https://dx.doi.org/10.24018/ejgeo.202.1.2.2.117. Vol2/Issue2/March 2021.
[8] GMI (2011): Landfill Methane Reducing Emissions, Advancing Recovery and Use Opportunities at www.globalmethane.org. Retrieved on February 23, 2018.

[9] Chang, S., Wanchi Huang and Shu-Liang, L (2010): "Municipal Solid Waste Management: A Comparison between the US and other Countries". Journal of Solid Waste Technology and Management 36.3(2010).

[10] Castillo-Gimenez, J.; Montanes, A.; Picazo-Tadeo, A.J. (2019): Performance and convergence in municipal waste treatment in the European Union. Waste Management 2019, 85,222-231[CrossRef] [PubMed]. In: Vaverkova, M.D. (2019): Landfill Impacts on the Environment - Review. Geosciences 2019, 9, 431; doi.10.3390/geosciences9100431. www.mdpi.com/jornal/geosciences.

[11] European Parliament. EU WM; Infographic with Facts and Figures; European Parliament: Strasbourg, France (2018): In: Vaverkova, M.D. (2019): Landfill Impacts on the Environment - Review. Geosciences 2019, $\quad 9, \quad 431 ; \quad$ doi.10.3390/geosciences9100431. www.mdpi.com/jornal/geosciences.

[12] Medero, G.M. (2017): Lecture notes of Environmental Geotechnics, School of the Built Environment, Heriot-Watt University, Edinburgh, United Kingdom. Unpublished.

[13] Kjeldsen, P., Barlaz, M.A., Rooker, A. P., Baun, A., Ledin, A., and Christensen, T.H. (2002): Present and Long-Term Composition of MSW Landfill leachate: A Review. Critical Reviews in Environmental Science and Technology 32(4), 297-336.

[14] Pablos, M.V., Martinin, F., Fernandez, C., Babin, M.M., Herraez, I., Miranda, J., Martinez, Garcia-Hortiguela, P., Tarazona, J.V. (2011): Correlation between physicochemical and ecotoxicological approaches to estimate Landfill leachates toxicity. Waste Management 31(8), 1841-1847.

[15] World's Population at www.worldometers.info/wold.population. Retrieved on June 5, 2021.

[16] Gilpin, A. (1995): Environmental Impact Assessment. Cambridge University Press ISBN 0521429676. In: Farombi, L (2012): Investigating the performance of Civil Engineering sustainable Project. A case study of Greenwich New Houses. MSc dissertation submitted to Heriot-Watt University, Edinburgh, United Kingdom.

[17] Tammemagi, H. (1999): The Waste Crisis: Landfills, Incinerators and the Search for a Sustainable Future. Oxford Press: New York.

[18] Wilson, D. C. (2007): "Development drivers for waste management". Waste Manage Res. 25, 198-207.

[19] Goelzer, B.I.F (n.d): The making of the Occupational Hygienist at www.goelzer.net/home/selected-publication/making-of----. Retrieved on February 10, 2018.

[20] Mikesell, R.F. (1994): Environmental assessment and sustainability at the project and program-level. In Goodland, R. and Edmundson, V. (eds). Environmental Assessment and Development, World Bank, Washington, D.C.

[21] Commission on Environmental Accounting (1991): In: Mikesell, R.F (1994): Environmental assessment and sustainability at the project and program-level. In Goodland, R. and Edmundson, V. (eds). Environmental Assessment and Development, World Bank, Washington, D.C.

[22] Longe, E.O. and Enekwschi, L.O. (2007): Investigation of Potential Groundwater Impacts and Influence of local Hydrogeology on Natural Attenuation of Leachate at a Municipal Landfill. International Journal of Environmental Science and Technology, 41(1), 133-140.

[23] Chapman, D. (1992): Water quality assessments - Guide to the use of biota, sediments and water in environmental monitoring. London: Chapman and Hall.

[24] Taylor, R. and Allen, A. (2006): Waste disposal and landfill: Potential hazards and information needs. In Schmoll, O; Howard, G.; Chilton, J.; and Chorus, I. (Eds): Protecting Groundwater for Health: Managing the Quality of Drinking-water Sources. London: IWA Publishing.

[25] Van Pelt, M.J.F (1993): Ecologically sustainable development in project appraisal in developing countries. Ecological Economics.

[26] O'Riordan, T. (1998): The politics of sustainability. In Thurner, R.K. (ed). Sustainable Environmental Management; Principles and Practice Belhaven Press, London.

[27] Goldemberg, J. (2000): Rural energy in developing countries. In: World Energy Assessment: Energy and the Challenge of Sustainability. UNDP, New York.

[28] ESI (2005): Benchmarking National Environmental Stewardship, Yale Centre for Environmental Law and Policy, Yale University.

[29] Avfall Sverige, (Swedish Waste Management) (2011): Swedish Waste Management 2011. Avfall Sverige, Malmo, Sweden.

[30] Naturvardsverket, (Swedish Environmental Protection Agency), Avfall i Sverige 2008(Waste in Sweden 2008), Naturvardsverket, Stockholm, 2010. In: Modin, H. (2012): Modern landfill leachate - quality and treatment Water Resources Engineering, Lund University, Sweden. 
[31] Vaverkova, M.D. (2019): Landfill Impacts on the Environment Review. Geosciences 2019, 9, 431; doi.10.3390/geosciences9100431. www.mdpi.com/jornal/geosciences. Retrieved June 17, 2021.

[32] Warrick, R.A., Riebsame, W. E. (1983): Societal response to $\mathrm{CO}_{2}$ induced climate change: opportunities for research. In: Chen, R.S., Boulding, E. and Schneider, S.H. (eds) Social Science Research and Climate Change: An Introductory Appraisal. D. Reidel Publishing Co. Dordrecht, Holland, P. 20-60.

[33] Renou, S., Givaudan, J.G., Poulain, S., Dirassouyan, F., Moulin, P. (2008): Landfill leachate treatment: Review and opportunity. Journal of Hazardous Materials 150:468-493.

[34] Ministry of Environment: A Guide for the Management of Closing and Closed Landfills in New Zealand at https://www.mfe.govt.nz. Retrieved on February 12, 2018.

[35] UNEP, (2010): Waste and Climate Change: Global trends and Strategy Framework. Division of Technology, Industry and Economics. International Environmental Technology Centre, Osaka/Shiga.

[36] Hjelmar, O., Hansen, E.A., Andersen, K.J., Andersen, J.B., Bjornestad, E. (1994): An Approach to the Assessment of Environmental Impacts of Marine Applications of Municipal Solid Waste Combustion Residues. In: Proceedings of WASCON 1994: Environmental Implications of Construction Materials and Technology Developments, Maastricht, The Netherlands, June 1-3, 1994.

[37] Nilsson. P. (1993): Optimising biogas by controlled deposition of solid waste. ISWA Yearbook 1993/94. International Directory of Solid Waste Management.

[38] Hjelmar, O., Hansen, E.A. and Rokkjaer, A. (1988): Groundwater contamination from an incinerator ash and household co-disposal site. In: Proceedings of UNESCO workshop on Impact of Waste Disposal on Groundwater and surface Water (pp. 155-171). Miljostyrelsen, Copenhagen, Denmark.

[39] Hjelmar, O. (1989): Characterisation of leachate from landfilled MSWI ash. In: Proceedings of the international Conference on Municipal Waste Combustion (Volume 1, pp. 3B1-3B19). US EPA and Environment Canada, Hollywood, Florida, USA.

[40] Ehrig, H.J. (1991): Control and treatment of landfill leachate. A review. Harwell 1991 Symposium: Challenges in Waste Management. AEA Harwell, UK.

[41] Gossele, P., Wefer, H., Nolting, B., and Bender, M. (1993): Long term investigation on selected landfill sites in the EC. In: T.H. Christensen, R. Cossu, and R. Stegmann (eds.): Sardinia 93, Proceedings of the Fourth International Landfill Symposium (II, pp. 1227-1236). CISA, Cagliari, Italy.

[42] Baldi, M., Bertanza, G., Collivignarelli, C., and Conti, T. (1993): Mathematical modelling of leachate quantity for an industrial sludge landfill. In: T.H. Christensen, R. Cossu, and R. Stegmann (eds.): Sardinia 93, Proceedings of the Fourth International Landfill Symposium (I, pp. 833-848). CISA, Cagliari, Italy.

[43] Kouzelli-Katsiri, A., Christoulas, D., and Bosdogianni, A. (1993): In: T.H. Christensen, R. Cossu, and R. Stegmann (eds.): Sardinia 93, Proceedings of the Fourth International Landfill Symposium (I, pp. 1007-1018). CISA, Cagliari, Italy.

[44] IPCC, (2001): IPCC Third Assessment Report. Cambridge University Press, Cambridge.

[45] Kaushal, A., Sharma, M.P. (2016): Methane Emission from Panki Open Dump Site of Kanpur, India. Procedia Environmental Sciences 35 (2016) 337-347.

[46] Kumar, S., Mondal, A.N., Gaikwad, S.A., Devotta, S. Singh, R.N. (2004): Qualitative assessment of methane emission inventory from Municipal Solid Waste disposal sites; a case study. Atmospheric Environment 38, 4921-4929.

[47] McCarthy, J.J. (2001): Climate Change: Impacts, Adaptation and Vulnerability. IPCC. Cambridge University Press.

[48] Saleh, M.A. (2015): BATNEEC Analysis of Solid Waste Disposal in Nigeria. An MSc Dissertation submitted to Heriot-Watt University, Edinburgh, Scotland, UK. August 2015.

[49] Lefebvre, X., Pommier, S., Akerman, A., Barina, G., and Budka, A. (2007): Analysis of the waste mass degradation in the context of functional stability of closed landfills Sardinia 2007, Eleventh International Waste Management and Landfill Symposium, CISA, Cagliari. In: Modin, H. (2012): Modern landfill leachate - quality and treatment Water Resources Engineering, Lund University, Sweden. Doctoral thesis.

[50] Scharff, H., Jacpbs, J. (2005): Equifll: inorganic waste landfill meeting EU landfill criteria. Sardinia 2005, Tenth International Waste Management and Landfill Symposium, CISA, Cagliari, Italy. In: Modin, H. (2012): Modern landfill leachate - quality and treatment Water Resources Engineering, Lund University, Sweden. Doctoral thesis.
[51] Laner, D., Crest, M., Scharff, H., Morris, J.W.F., and Barlaz, M.A. (20120: A review of approaches for the long-term management of municipal solid waste landfills. Waste Management 32(3) 498-512. In: Modin, H. (2012): Modern landfill leachate - quality and treatment Water Resources Engineering, Lund University, Sweden. Doctoral thesis.

[52] CEC (2003): Council Decision 2003/33/EG of 19 December 2002 establishing Criteria an Procedures for Acceptance of Waste at Landfills Pursuant to Article 16 and Annex11 of Directive1999/31/EC on the Landfill of Waste. Official Journal of the European Communities. In: Scharff, H., Zomeren, A. van., Sloot, H. A. van der (2007): Landfill sustainability and aftercare criteria. Waste Management and Research 29(1) 30-40.

[53] Scharff, H., Jacobs, J., van der Sloot, H., and van Zomeren, A. (2007): Inorganic waste landfill and final storage quality. In: Scharff, H., Zomeren, A. van., Sloot, H. A. van der (2007): Landfill sustainability and aftercare completion criteria. Waste Management and Research 29(1) 30-40.

[54] Westakle, K (n.d): Sustainable Landfill - possibility or pipe dream, Waste management and research 15 (1997), 453-461. In: Varga, G. (2011): Some geotechnical aspects of bioreactor landfills. Doi;10.3311/pp.ci.2011-1.05.

[55] Varga, G. (2011): Some geotechnical aspects of bioreactor landfills. Doi; $10.3311 /$ pp.ci.2011-1.05.

[56] Jamal, H. (2017): Solid Waste Landfill Site Selection available at https://www.aboutcivil.org/solid-waste-landfill-site-selection.html. Retrieved on February 2, 2018.

[57] Pohland, F.G, and Harper, S.R. (1986): Critical Review and Summary of Leachate and Gas production From Landfills, Cincinnati, OH U.S.A.: U.S. Environmental Protection Agency, 1986. EPA/600/286/073. In: Varga, G. (2011): Some geotechnical aspects of bioreactor landfills. Periodica Polytechnica Civil Engineering. Doi;10.3311/pp.ci.2011-1.05; http://www.pp.bme.hu/ci.

[58] Read, A.D. Hudgins, M., Philips, P. (2001): Aerobic landfill test cells and their implications for sustainable waste disposal. Geographical Journal 167, 235-247. In: Modin, H. (2012): Modern landfill leachate - quality and treatment Water Resources Engineering, Lund University, Sweden.

[59] Binner, E. (2002): The Impact of Mechanical-Biological Pretreatment on the Landfill Behaviour of Solid Waste. Workshop Biowaste, ABF BOKU, Brussels. In: Modin, H. (2012): Modern landfill leachate quality and treatment Water Resources Engineering, Lund University, Sweden.

[60] Robinson, H.D. Knox, K. Bone, B.D and Picken, A. (2005): Leachate quality from landfilled MBT waste. Waste Management 25(4), $383-$ 391. In; Modin, H. (2012): Modern landfill leachate - quality and treatment Water Resources Engineering, Lund University, Sweden.

[61] Mor, S.; Ravindra, K.; Visscher, A.D.; Dahiya, R.P.; Chandra, A Municipal solid waste characterization and its assessment for potential methane generation: A case study. Sci. Total Environ. 2006, 371, 1-10. In: Zhang, C., Xu, T., Feng, H., Chen, S. (20190: Greenhouse Gas Emission from Landfills: A Review and Bibliometric Analysis. MDPI. Published on April 16, 2019.

[62] Siddiqui, F.Z.; Khan, M.E.; Rajaram, R. From Landfill Gas to Energy: Technologies and Challenges; CRC Press: Boca Raton, FL, USA, 2012. In: Zhang, C., Xu, T., Feng, H., Chen, S. (20190: Greenhouse Gas Emission from Landfills: A Review and Bibliometric Analysis. MDPI. Published on April 16, 2019. 